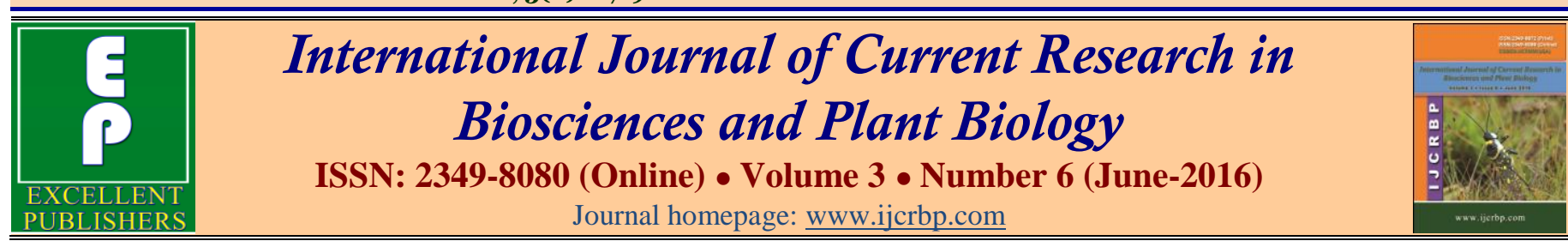

\title{
Scientific Evaluation of Traditionally Known Insulin Plant Costus Species for the Treatment of Diabetes in Human
}

\author{
M. Ferosekhan', A. Ramu ${ }^{1}$ and S. Ravikumar ${ }^{2 *}$ \\ ${ }^{1}$ Department of Chemistry, Madurai Kamaraj University, Madurai-625 021, Tamil Nadu, India \\ 2Department of Oceanography and Coastal Area Studies, Alagappa University, Thondi Campus, Thondi - 623 409, \\ Tamil Nadu, India \\ *Corresponding author.
}

\begin{tabular}{|c|c|}
\hline Abstract & Article Info \\
\hline $\begin{array}{l}\text { Medicinal plants have a long history of use and their use is widespread in both } \\
\text { developing and developed countries. From the last few decades, there is an increasing } \\
\text { interest in formation of the drugs derived from plants which helps to control diseases. }\end{array}$ & $\begin{array}{l}\text { Accepted: } 18 \text { May } 2016 \\
\text { Available Online: 06 June } 2016\end{array}$ \\
\hline $\begin{array}{l}\text { Also the herbal products are safer than synthetic products which may be harmful and } \\
\text { unsafe to the human and environment. The present study made an attempt to find out the }\end{array}$ & Ke y w o r d s \\
\hline $\begin{array}{l}\text { antidiabetic property of Costus species. Fresh elder leaves of species viz., Costus pictus } \\
\text { and Costus speciosus were collected from Western Ghats, Tamil Nadu. The plant } \\
\text { samples were washed thoroughly and extracted in ethanolic solvent. In in vitro a- } \\
\text { amylase inhibitory study, the maximum inhibition of Costus pictus was of } 88.75 \% \text { at a } \\
\text { concentration } 400 \mu \mathrm{g} \cdot \mathrm{ml}^{-1} \text {. In starch iodine color assay, the maximum inhibition of color } \\
\text { change of extract at } 400 \mu \mathrm{g} \cdot \mathrm{ml}^{-1} \text {. Glucose uptake inhibition assay data suggests Costus } \\
\text { species is significant in inhibiting glucose diffusion. It is concluded from the present } \\
\text { study that the Costus species extracts potentiate the antidiabetic activity and can be used } \\
\text { as an alternate for the treatment of diabetes after completing successful clinical trials. }\end{array}$ & $\begin{array}{l}\text { Costus pictus } \\
\text { Costus speciosus } \\
\text { Diabetes } \\
\text { Insulin plant } \\
\text { Medicinal plants }\end{array}$ \\
\hline
\end{tabular}

\section{Introduction}

Diabetes mellitus is a major health problem for the people of the world and is a chronic disorder/ syndrome resulting from a variable interaction of hereditary and environmental factors and is characterized by abnormal insulin secretion or insulin receptor or post receptor events affecting metabolism involving carbohydrates, proteins and fats in addition to damaging liver, kidney and pancreatic cells. The number of people suffering from the disease worldwide is increasing at an alarming rate with a projected 366 million people likely to be diabetic by the year 2030 as against 191 million estimated in 2000. In modern medicine no satisfactory effective therapy is still available to cure diabetes mellitus (Kumudhavalli and Jaykar, 2012). Though insulin therapy is also used for the management of diabetes mellitus, the medicinal plants in modern medicine is used in the world to prevent or to cure diseases. The plant Costus pictus is cultivated in Uttarkannada of Karnataka in India and the people in this area take traditionally 2-3 leaves of this plant twice a day for the management of diabetes (Lyra et al., 2006). It is prostrate growing plant with spreading rooting stems. Costus speciosus is also found in various parts of India, Taiwan and Malaysia. It is succulent plant with long simple spirally arranged leaves and spirally twisted stems and has horizontal rhizomes. The rhizomes are used in constipation, skin diseases, fever, asthma, bronchitis, inflammation and anemia and are medicinally tried to utilize for antihelminthic, astringent, purgative and aphrodisiac properties (Basha and Kumari, 2012). The alkaloidal function from Costus speciosus was evaluated 
for anticholinesterase activity and was later demonstrated to possess papaverine like smooth muscle relaxant action, diuretic, cardiotonic and central nervous system depressant activities. It was recognized as a source of diosgenin and the saponin content was found to have antifungal activity (Kim et al, 2005). Traditionally this rhizome has been used for many inflammatory conditions in fever. Recent works proved that, extracts from insulin plant exhibited activity against human, animal and plant pathogens. However, no attempt has been taken so far on the scientific evaluation of the medicinal properties of Costus species for the treatment of diabetics in human and hence the present study has been undertaken.

\section{Materials and methods}

\section{Collection and extraction of bioactive compounds}

Fresh elder leaves of species viz., Costus pictus and Costus speciosus were collected from Western Ghats, Tamil Nadu. Leaves were washed thrice in sterile distilled water to remove the epiphytes. Samples were shade dried and powdered. The powdered leaves of $500 \mathrm{~g}$ were soaked in 1 litre of ethanol water mixture (3:1) for 10 days in an air tight clean glass container and the contents were mixed every day so as to enable the maximum extraction of bioactive compounds. After that, the solvent containing bioactive extracts were filtered through muslin cloth and kept in the rotary flash evaporator (with solvent trap) to obtain solvent free extract residue and the extract residue was stored in refrigerator for further use. The presence of saponins, tannins, alkaloids, flavonoids, anthraquinones, glycosides and reducing sugars in the extract were tested by following simple and standard qualitative methods earlier described by Sofowora (1993). Triplicates were maintained throughout the experiment and the results were statistically analysed for significance.

\section{In vitro anti-hyperglycemic activity-3, 5-dinitro- salicylic acid method (DNSA)}

The inhibition assay was performed according to Miller (1959) using DNS method. Plant extract of varied concentrations (100 to $400 \mu \mathrm{g} \cdot \mathrm{ml}^{-1}$ ) were added to $500 \mu \mathrm{l}$ of $0.02 \mathrm{M}$ sodium phosphate buffer (pH 6.9 containing 6 $\mathrm{mM}$ sodium chloride) containing 0.04 units of $\alpha$-amylase solution and were incubated at $37^{\circ} \mathrm{C}$ for $10 \mathrm{~min}$, followed by addition of $500 \mu \mathrm{l}$ of a $1 \%$ starch solution in $0.02 \mathrm{M}$ sodium phosphate buffer ( $\mathrm{pH}$ 6.9) all the test tubes. The reaction was stopped with $1.0 \mathrm{ml}$ of 3,5 DNSA reagent. The test tubes were then incubated in a boiling water bath for $5 \mathrm{~min}$ and cooled to room temperature. The reaction mixture was then diluted after adding $10 \mathrm{ml}$ distilled water and absorbance was measured at $540 \mathrm{~nm}$. The control samples were also prepared accordingly without any plant extracts and were compared with the test sample containing various concentrations of the plant extracts. The results were expressed as \% inhibition calculated using the formula: $\%$ inhibition activity $=\mathrm{Abs}$ (control) - Abs $($ Extract)/Abs control $\times 100$.

\section{Starch-iodine color assay}

Screening of plant extract for $\alpha$-amylase inhibitors was carried out according to Xiao et al. (2006) with slight modification based on the starch-iodine test. Plant extracts of varied concentrations (100 to $400 \mu \mathrm{g} \mathrm{m}{ }^{-1}$ ) were added to $500 \mu \mathrm{l}$ of $0.02 \mathrm{M}$ sodium phosphate buffer (pH6.9 containing $6 \mathrm{mM}$ sodium chloride) containing 0.04 units of $\alpha$-amylase solution and were incubated at $37^{\circ} \mathrm{C}$ for $10 \mathrm{~min}$. Then $500 \mu \mathrm{l}$ soluble starch $(1 \%$, w/v) was added to each reaction well and incubated at $37^{\circ} \mathrm{C}$ for $15 \mathrm{~min}$. $1 \mathrm{M} \mathrm{HCl}(20 \mu \mathrm{l})$ was added to stop the enzymatic reaction, followed by the addition of $100 \mu \mathrm{l}$ of iodine reagent $(5 \mathrm{mM} \mathrm{I} 2$ and $5 \mathrm{mM} \mathrm{KI})$. The colour change was noted and the absorbance was read at $620 \mathrm{~nm}$ on a microplate reader. The control reaction representing $100 \%$ enzyme activity did not contain any plant extract. To eliminate the absorbance produced by plant extract, appropriate extract controls without the enzyme were also included. Inhibition of enzyme activity was calculated as Inhibition of enzyme activity $(\%)=(\mathrm{C}-\mathrm{S}) /$ $\mathrm{C} \times 100$, where $\mathrm{S}$ is the absorbance of the sample and $\mathrm{C}$ is the absorbance of blank (no extract).

\section{Glucose uptake in yeast cells}

Yeast cells were prepared according to the method of Narkhede et al. (1962). Briefly, commercial baker's yeast was washed by repeated centrifugation $(3,000 \mathrm{rpm}$ for 5 min) in distilled water until the supernatant fluids were clear and a $10 \%(\mathrm{v} / \mathrm{v})$ suspension was prepared in distilled water. Various concentrations of extracts (100 to 400 $\left.\mu \mathrm{m} . \mathrm{ml}^{-1}\right)$ were added to $1 \mathrm{ml}$ of glucose solution $(5,10$ and $25 \mathrm{mM}$ ) and incubated together for $10 \mathrm{~min}$ at $37^{\circ} \mathrm{C}$. Reaction was started by adding $100 \mu \mathrm{l}$ of yeast suspension, vortexed and further incubated at $37^{\circ} \mathrm{C}$ for $60 \mathrm{~min}$. After $60 \mathrm{~min}$, the tubes were centrifuged $(2,500 \mathrm{rpm}$ for $5 \mathrm{~min})$ and glucose was estimated in the supernatant. Metformin was taken as standard drug. The percentage increase in glucose uptake by yeast cells was calculated using the following formula: Increase in glucose uptake $(\%)=\mathrm{Abs}$ sample - Abs control/Abs sampleX100, where, Abs control is the absorbance of the control reaction 
(containing all reagents except the test sample), and Abs sample is the absorbance of the test sample. All the experiments were carried out in triplicates.

\section{Glucose movement by using dialysis membrane}

A simple model system for in vitro study was adapted from the method described by Bhurat et al. (2011). Briefly, the model used in the present experiment consisted of a onesided sealed dialysis tube $(15 \mathrm{~cm} \times 25 \mathrm{~mm}$,dialysis tubing membrane Himedia, Mumbai, India) into which $2 \mathrm{ml}$ of $22 \mathrm{mM}$ D-glucose in $0.15 \mathrm{M} \mathrm{NaCl}$ and $1 \mathrm{ml}$ different concentration of extracts (100 to $400 \mu \mathrm{m} / \mathrm{ml}) /$ control (water) were incorporated. The other end was then sealed and the membrane was placed into a conical flask containing $45 \mathrm{ml}, 0.15 \mathrm{M} \mathrm{NaCl}$. The conical flask was placed into an orbital shaking incubator at $37^{\circ} \mathrm{C}$ and speed of 100 rotations per minute. Aliquote $(10 \mu \mathrm{l})$ of the external solution was withdrawn at timed intervals and tested for the presence of glucose using a glucose oxidase kit (Biosystems, Spain). As described by Aly et al. (2010) concentration dependent effect of extracts that exhibited the highest glucose diffusion retardation index was also evaluated. A standard curve was drawn using different glucose concentrations. Experiments were conducted in triplicate. The glucose diffusion retardation index (GDRI) was calculated using the following formula. GDRI $=(100-$ glucose content $(\mathrm{mg} / \mathrm{ml})$ in external solution in the presence of plant extract/glucose content $(\mathrm{mg} / \mathrm{ml})$ in external solution in the absence of plant extract) $\times 100$.

\section{Statistical analysis}

Data are expressed as mean \pm S.E.M. Statistical comparisons between groups were done by one way analysis of variance (ANOVA) followed by Tukey Kramer multiple comparison tests to analyze the differences. $p<0.05$ was considered as significant.

\section{Results and discussion}

As the number of people with diabetes multiplies worldwide, the disease takes an ever increasing proportion of national and international health care (Abdel Mageed, 2005) budget. It is projected to become one the world main killers within the next 25 years. Regions with greatest potential are Asia and Africa, where DM rates could rise to two or three folds than the present rate. Apart from currently available therapeutic options, many herbal medicines have been recommended for the treatment of diabetes. Traditional plant medicines are used throughout the world for a range of diabetic complications (Bhandari et al., 2008). The findings of this study pave the way to further explore the antidiabetic potential of Costus species for world-wide use, and especially in India. Even though a few peripheral studies have been reported on anti diabetic and phytochemical constituents of Costus species and investigation are also in progress in different laboratories none of them is much informative (Iniyan et al., 2011). The maximum inhibition of Costus pictus was of $88.75 \%$ at a concentration $400 \mu \mathrm{g} \mathrm{ml} \mathrm{ml}^{-1}$. The percentage inhibition ranged from $88.75 \%$ to $78.65 \%$. Costus speciosus showed percentage maximum inhibition of $87.25 \%$ at $400 \mu \mathrm{g} \cdot \mathrm{ml}^{-1}$. At the lowest concentration $100 \mu \mathrm{g} \mathrm{ml} \mathrm{m}^{-1}$, there was about $78.75 \%$ inhibition. In the present study in vitro $\alpha$-amylase inhibitory studies demonstrated that both Costus species had inhibitory activity Table 1. $\alpha$-amylase is a key enzyme in digestive system and catalyses the initial step in hydrolysis of starch to maltose and finally to glucose. Degradation of this dietary starch proceeds rapidly and leads to elevated postprandial hyperglycemia. It has been shown that activity of human $\alpha$-amylase correlates to an increase in postprandial glucose level, the control of which is therefore an important aspect in treatment of diabetes.

Table 1. Inhibition of $\alpha$ amylase activity by crude extracts from Costus species.

\begin{tabular}{llll}
\hline Name of the plant species & Concentration $\left(\boldsymbol{\mu g} \cdot \mathbf{m l}^{-\mathbf{1}}\right)$ & O.D at $\mathbf{6 6 0} \mathbf{~ n m}$ & Percentage inhibition \\
\hline Costus pictus & 100 & $1.7 \pm 1.21^{*}$ & $78.75 \%$ \\
& 200 & $1.4 \pm 2.83$ & $82.50 \%$ \\
& 300 & $1.2 \pm 2.1^{*}$ & $88.21 \%$ \\
& 400 & $1.9 \pm 2.8^{* * *}$ & $88.75 \%$ \\
Costus speciosus & 100 & $0.1 \pm 1.84$ & $25.35 \%$ \\
& 200 & $0.3 \pm 1.39 *$ & $32.12 \%$ \\
& 300 & $1.2 \pm 1.3 * * *$ & $36.25 \%$ \\
& 400 & $1.6 \pm 1.8$ & $87.25 \%$ \\
Positive control (Metformin) & 400 & 0 & $95.68 \%$ \\
Negative control & 0 & 0 \\
\hline Values are expressed as mean \pm SEM of triplicate; Data were analyzed using one way ANOVA followed by Tukey Kramer \\
multiple comparison test; $p \leq 0.05$ compared to control; $* * *$ Represents statistical significance Vs control $(p<0.001) ;$ \\
$* *$ Represents statistical significance Vs control $(p<0.01) ; *$ Represents statistical significance Vs control $(p<0.05)$.
\end{tabular}


Table 2 shows the presence of inhibitors from the extracts the starch added to the enzyme assay mixture is not degraded and gives a dark-blue colour complex whereas no colour complex is developed in the absence of the inhibitor, indicating that starch is completely hydrolyzed by $\alpha$-amylase. The maximum inhibition of color change of extract was at $400 \mu \mathrm{g} \cdot \mathrm{ml}^{-1}$. Glucose uptake inhibition assay are depicted in Table 3. The data suggests Costus species is significant in inhibiting glucose diffusion which in turn states that the plant is capable of regulation glucose movement out of the cells into the blood stream thereby controlling post prandial glucose levels. Phytochemical screening of active plant extracts was done by following standard methods (Prashanth et al., 2001) for the qualitative analysis of various phytochemical studies such as alkaloids, carbohydrate, glycosides, saponins, flavonoids and phenols, which could be responsible for antidiabetic activity. Phytochemical screening of the rhizome extracts of Costus species revealed the presence of different phytochemicals, indeed phytochemical investigations of this plant have resulted in occurrences of carbohydrates, alkaloids, glycosides, saponins, flavonoids, and Table 4 illustrates the results of phytochemical screening of the extracts of Costus species.

Table 2. Effect of Costus species plant extract in the starch iodine color assay.

\begin{tabular}{|c|c|c|c|}
\hline Name of the plant species & Concentration $\left(\mu \mathrm{g} \cdot \mathrm{ml}^{-1}\right)$ & O.D at $660 \mathrm{~nm}$ & Percentage inhibition \\
\hline \multirow[t]{4}{*}{ Costus pictus } & 100 & $1.7 \pm 2.15^{* *}$ & $78.75 \%$ \\
\hline & 200 & $1.4 \pm 1.54$ & $82.50 \%$ \\
\hline & 300 & $1.2 \pm 1.4$ & $85 \%$ \\
\hline & 400 & $0.9 \pm 0.98 * * *$ & $88.75 \%$ \\
\hline \multirow[t]{6}{*}{ Costus speciosus } & 100 & $0.2 \pm 1.65$ & $26.35 \%$ \\
\hline & 200 & $0.6 \pm 1.87 * *$ & $32.36 \%$ \\
\hline & 300 & $0.9 \pm 1.39$ & $45.64 \%$ \\
\hline & 400 & $1.3 \pm 1.7 * * *$ & $65.32 \%$ \\
\hline & 400 & $2.3 \pm 2.61$ & $99.64 \%$ \\
\hline & 0 & 0 & 0 \\
\hline
\end{tabular}

Values are expressed as mean \pm SEM of triplicate; Data were analyzed using one way ANOVA followed by Tukey Kramer multiple comparison test; $p \leq 0.05$ compared to control; *** Represents statistical significance Vs control $(p<0.001)$;

** Represents statistical significance Vs control $(p<0.01)$; * Represents statistical significance Vs control $(p<0.05)$.

Table 3. Inhibition of glucose uptake by dialysis membrane by the crude extracts from Costus species.

\begin{tabular}{llll}
\hline Name of the plant species & Concentration $\left(\boldsymbol{\mu g} . \mathbf{m l}^{\mathbf{1}}\right)$ & O.D at $\mathbf{6 6 0} \mathbf{~} \mathbf{m}$ & Percentage inhibition \\
\hline Costus pictus & 100 & $1.7 \pm 2.43^{*}$ & $28.75 \%$ \\
& 200 & $1.4 \pm 2.78$ & $32.50 \%$ \\
& 300 & $1.2 \pm 0.94^{*}$ & $45.32 \%$ \\
Costus speciosus & 400 & $0.9 \pm 1.87$ & $78.75 \%$ \\
& 100 & $0.2 \pm 0.63$ & $23.65 \%$ \\
& 200 & $0.6 \pm 1.43$ & $36.15 \%$ \\
& 300 & $0.9 \pm 1.48^{* *}$ & $41.25 \%$ \\
400 & $1.6 \pm 0.98$ & 69.54 \\
400 & $2.6 \pm 2.76^{* * *}$ & 86.95 \\
\hline
\end{tabular}

Values are expressed as mean \pm SEM of triplicate; Data were analyzed using one way ANOVA followed by Tukey Kramer multiple comparison test; $p \leq 0.05$ compared to control; *** Represents statistical significance Vs control $(p<0.001)$; **

Represents statistical significance Vs control $(p<0.01)$; * Represents statistical significance Vs control $(p<0.05)$.

The bioactivity of plant products mainly depends on the amount of the major active constituents. Based on the above findings, it can be concluded that the antidiabetic activity of Costus species could be due to the presence of a phytochemical flavonoids in the plant. However, the above mentioned active constituent has to be isolated, characterized and evaluated for antidiabetic activity in comparison with reference compound. To the best of our knowledge, this is the report on antidiabetic and phytochemical investigation of Costus pictus and Costus speciosus even though a few peripheral information and lacking scientifically reported study on the properties of these plants, especially based on antidiabetic activity despite its wide usage as medicinal plant. 
Table 4. Phytochemical constituents reported in the Costus species.

\begin{tabular}{lll}
\hline Phytochemical constituents & Response & Costus speciosus \\
\cline { 2 - 3 } & Costus pictus & + \\
Alkaloids & + & - \\
Carboxylic acids & + & - \\
Coumarins & - & + \\
Flavonoids & + & - \\
Phenols & + & - \\
Quinones & + & + \\
Saponins & + & - \\
Tannins & + & + \\
Xanthoproteins & + & + \\
Sugars & - & - \\
Steroids & + & + \\
Anthraquinones & - & + \\
Anthracene & + & + \\
Glycosides & + & + \\
Proteins and free amino acids & + & \\
\hline
\end{tabular}
+ positive - negative

\section{Conflict of interest statement}

Authors declare that they have no conflict of interest.

\section{References}

Abdel-Mageed, N. A., 2005. Efficacy of some antioxidants on certain biochemical parameters in blood of diabetic rats. Egypt. Pharm. J. 4, 125-134.

Aly, H. F., Ebrahim, M. E., Metawaa, H. M., Hosni, E. A. A., Ebrahim, F. M., 2010. In vitro and in vivo evaluation of the antidiabetic effect of different extracts of Nepeta cataria in streptozotocin induced diabetic rats. J. Amer. Sci. 6(10), 364-386.

Basha, S. K., Kumari, V. S., 2012. In vitro antidiabetic activity of Psidium guajava leaves extracts. Asian Pac. J. Trop. Dis. S98-S100

Bhandari, M. R., Anurakkun, N. J., Hong, G., Kawabata, J., 2008. $\alpha$-Glucosidase and $\alpha$-amylase inhibitory activities of Nepalese medicinal herb Pakhanbhed (Bergenia ciliata Haw.) .Food Chem. 106, 247-252.

Bhurat, M.R., Sapakale, H.S., Salunkhe, K.G., Sanghavi, R.S., Kawatikwar, P.S., 2011. Preliminary chemical evaluation and in vitro anti-inflammatory activity of leaves of Remusatia vivipara. Asian J. Biochem. Pharmaceut. Res. 2(1), 303-306.

Iniyan, G. T., Dineshkumar, B., Nandhakumar, M., Senthilkumar, M., Mitra, A., 2011. In vitro study on $\alpha$ - amylase inhibitory activity an Indian medicinal plant. Ind. J. Phramacol. 42(5), 280-282.

Kim, Y. M., Jeong, Y. K., Wang, M. H., Lee, W. Y., Rhee, H. I., 2005. Inhibitory effect of pine extract on alphaglucosidase activity and postprandial hyperglycemia. Nutrition. 21, 756-761.

Kumudhavalli, M. V., Jaykar, B., 2012. Evaluation of antidiabetic activity of Costus igneus (L.) leaves on STZ induced diabetic rats. J. Der Pharm. Sinica. 3(1), 1-4.

Lyra, R.M., Oliveira, D., Lins, N., Cavalcanti, N., 2006. Prevention of type 2 diabetes mellitus. Arq. Brasil. Endocrinol. Metabol. 50, 239-249.

Miller, G. L., 1959. Use of dinitrosalicylic acid reagent for determination of reducing sugar. Anal. Chem. 31, 426428.

Narkhede, M. B., Ajimire, P. V., Wagh, A. E., Mohan, M., Shivashanmugam, A. T., 2011. In vitro antidiabetic activity of Caesalpinia digyna (R.) methanol root extract. Asian J. Plant Sci. Res. 1(2), 101-106.

Prashanth, D., Padmaja, R., Samiulla, D.S., 2001. Effects of certain plant extracts on alpha amaylase activity, J. Fitoter. $72,179-181$.

Sofowora, A., 1982. Medicinal Plants and Traditional Medicine in Africa. Wiley, New York. 251p.

Xiao, Z., Storms, R., Tsang, A., 2006. A quantitative starchiodine method for measuring alpha-amylase and glucoamylase activities. Anal. Biochem. 351(1), 146-148.

\section{How to cite this article:}

Ferosekhan, M., Ramu, A., Ravikumar, S., 2016. Scientific evaluation of traditionally known insulin plant Costus species for the treatment of diabetes in human. Int. J. Curr. Res. Biosci. Plant Biol. 3(6), 87-91.

doi: http://dx.doi.org/10.20546/ijcrbp.2016.306.011 